\title{
Do Literary Studies have a present? Five SNAPShots OF AN INSTITUTIONAL VoID
}

\author{
Os estudos literários têm um presente? Cinco \\ retratos de um vazio institucional
}

\author{
Hans UlRich Gumbrecht \\ Stanford University, Palo Alto, California, EUA \\ E-mail: sepp@stanford.edu
}

\begin{abstract}
The future of literary studies depends on the acknowledgment of its present. After the emergence of post-theoretical times, in the 1990s, the academy faces a discontinuity with the intellectual projects of the twentieth century, which results in an experience of institutional void. The created space allows idiosyncratic practices, without a characterization of a disciplinary profile. In order to think about an institutional continuation of literary studies, it is necessary to recognize this void-like quality that the present times exhibit.
\end{abstract}

KEYWORDS: Post-theory; literary studies; humanities.

EDITORES:

Regina Zilberman

Gerson Roberto Neumann

SUBMETIDO: 13.09 .2020

ACEITO: 02.11.2020

\section{COMO CITAR:}

GUMBRECHT, Hans Ulrich.

Do Literary Studies have a present? Five Snapshots of an Institutional Void. Rev. Bra. Lit. Comp., v. 23, n. 42, p. 17-20, jan./abr., 2021. doi: https:// doi.org/10.1590/2596$304 \times 20212342$ hug

\section{RESUMO}

O futuro dos estudos literários depende do reconhecimento de seu presente. Após o surgimento dos tempos pós-teóricos, na década de 1990, a academia vê uma descontinuidade com os projetos intelectuais do século $\mathrm{XX}$, o que resulta numa experiência de vazio institucional. O espaço criado permite práticas idiossincráticas, sem uma caracterização de um perfil de disciplina. Para pensar-se uma continuação institucional dos estudos literários, é necessário reconhecer essa qualidade de vazio que a atualidade apresenta.

PALAVRAS-CHAVE: Pós-teoria; estudos literários; humanidades.

\section{I}

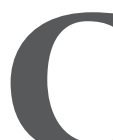

ollective memory today associates the year 1990 with the collapse of State Socialism. But for my generation of mid-century born critics and without any political denotation in the strict sense of the word, it also marks the beginning of post-theoretical times in Literary Studies. For two main reasons this intellectual discontinuity and its consequences took us by surprise. Firstly because our academic discipline had gone through some forty years of permanent epistemological and demographic expansion at whose culminating point Literary Theory, as its conceptual condensation, was occupying the center of the Humanities and Arts (and it 
did so to a degree that had progressively dissolved its traditional focus on phenomena of "literature"). Secondly and above all, the post-theory event took us by surprise because it did not seem to emerge from any internal crisis or malfunctioning. Nobody had seen it coming indeed, after those decades of intense productivity and often hectic change. As we had rather expected our work to be in even higher demand within such a moment of political transition, it finally had to be the sheer lack of innovative paradigms and impulses, i.e. the shocking experience of a void, that forced us to grudgingly acknowledge discontinuity.

Thirty years later, we may try to react in a more composed fashion. All institutions that have had a beginning will come to their ending at some point, and human kind tends to survive. If the foundation of Literary Studies inside the larger framework of the Humanities and Arts had been inspired by the emergence of the so-called "historical world view" between 1780 and 1830, i.e. by the belief that time was a necessary agent of ultimately calculable change; and if that belief had assigned us humanists the ongoing ask of identifying each new present (and thus become "symptomatologists of the present," as Jean-François Lyotard once famously said); then the at first invisible but soon irreversible vanishing of this thinking pattern (since the mid-twentieth century) and its (contemporary) substitution by a different construction of time may have undercut the professional traditions we had grown up with. In other words: should the historical world view ever completely disappear there will be no return to Literary Studies as we have known them.

\section{III}

Trying to describe the conditions of such an ending may be the final task remaining, or at least the one challenge that younger generations need to come to terms with before they can look for perspectives and goals for Literary Studies in a profoundly changed environment. We should therefore learn to see the present of Literary Studies as a void between an ending that we have not yet fully understood and a potential beginning that probably will not come under way before we manage to do so. The final stage in the sequence of ever-renewed theory moments within Literary Studies was (and still is) occupied by a focus on phenomena of multiple dimensions of "identity," and as innovations and substitutions have stopped to happen, our discipline got stuck with this identity obsession. Francis Fukuyama who had been the first to diagnose the "end of history" (in exactly the same sense that I have described the vanishing of the historical world view) suggests that "identity" became a contagious topic since the moment that the ("historical") dynamic of an ever changing present ceased. From identifying each new present, the focus switched to the different "identities" of a fast growing number of social groups (or "cultures") which, different from the sequence of present moments within the historical world view, considered themselves to be stable. As those different "identities" stayed in lasting contemporaneity and juxtaposition they became concerned with equality. Each social group and each culture wants to be different from all the others while, at the same time and paradoxically, they are concerned with equality, i.e. with receiving at least the same respect and recognition as all other groups and cultures. The more they push for identity and difference, however, the more they feel threatened to lose equality 
(and vice versa). Much of what is left of Literary Studies, Cultural Studies, and especially Postcolonial Studies has been caught and paralyzed in this vicious circle.

\section{IV}

At the same time and not independently from the vanishing of the historical world view, the predominant style of political communication (as a type of communication that humanists have long tended to engage in) has undergone a transformation. Not only in the United States and in Brazil the public sphere and the emblematic political institutions no longer function by competition, confrontation and argument, as they had been established during the age of Enlightenment and the bourgeois Revolutions - but rather by structures and mechanics of resonance. The $45^{\text {th }}$ President of the United States, for example, excels in producing resonance and adherence (without any specific content) with large crowds in real presence and among the millions of people who follow him through electronic media. He can thus afford an incoherence of content and a political practice without stable goals that may well correspond to a frame of temporality no longer implying permanent change (if the future is no longer supposed to be different from the present then there is no space for any goals or projects). Quite paradoxically, however, political correctness as the self-declared global opposition to politics of resonance functions by resonance itself. For as it opts for the further development and expansion of the welfare state it acts as if the historical world view (i.e. matrix of the welfare state vision of life) was still alive and available. There is no genuine analysis of the present situation in politically correct circles, just a blind opposition to whatever is different from the historical world view and from the welfare state - and a blind adherence to principles and values that have long vanished. Now the fact that both camps in our political world share the style of resonance may explain why so many societies today appear split without any hope for reconciliation. Everywhere resonance is replacing arguments in politics at this point. And instead of trying to develop fresh concepts and perspectives with the goal of understanding the new situation, many Literary Critics opt for political correctness (which also implies a denial of the most decisive change in their disciplinary situation, that is a denial of the vanishing of the historical world view). Needless to say, identity studies and political correctness are bound to dovetail, often to the point of being hard to distinguish. Above all, identity studies and political correctness occupy an institutional space that had been created for much more ambitious intellectual endeavors. But as they now exist in the repetition of certain formulas, rituals, and above policing activities, they produce the impression of barely filling a void.

\section{V}

Beside Cultural Studies and political correctness, the empty present of Literary Studies that stretches between a vanished (sometimes glorious) past and an unknown possible future (that yet has to begin) offers space for many other activities, some of them weirdly idiosyncratic, others quite outstanding in their quality. But they all do not add up to something like the "profile" of a discipline or its "state of the art." As a now remote legacy from the heydays of Literary Theory as core of the Humanities and Arts, the more recent activities still come with a focus that goes beyond phenomena of "literature" in the more specific sense. You can be "political" or "philosophical," "postcolonial" or 
"global," "media-obsessed" or "didactic" in Literary Studies - without anybody calling you to order (or excluding you from professional promotion). Against this background, it appears remarkable that an increasing number of students within the contemporary cohorts (from freshmen to doctoral level) profess their love for literature - without apologies, new theories, or claims of aesthetics sophistication. They simply seem to assume that a discipline called "Literary Studies" must be the institutional home for their enthusiasm. To mention just one example: there is a group of students in the Department of Comparative Literature at Stanford who, without requiring any faculty support or advice, meets on a weekly basis to indulge in the tough reading work of deciphering James Joyce's "Finnegan's Wake." Rather than complementing or commenting this adventure with philosophical books or debates, many of these students pursue literary writing projects of their own (mostly at distance from the academic programs of "Creative Writing"). Politics for them do not seem to belong to the same horizon of existential concern as their passion for reading and writing; they do not necessarily embrace (or reject) positions of the Left; nor do they engage in polemics with their colleagues who fulfill the rituals of Cultural Studies or political correctness. Should one interpret such activities as a symptom for a future of Literary Studies (again that old habit of acting as a symptomatologist!)? Such a claim would imply that the new students can sense a continuity between their own irresistible passion for literature and the intellectual past of Literary Studies - which I believe they do not find interesting at all (with all due politeness). Perhaps their presence and visibility can help us save some academic positions for midcareer colleagues but beside that I do not see a continuity between what is left of Literary Studies and the new students that would be worth cultivating. To pretend that a continuity exists may well look like an act of bad faith. So perhaps it is really helpful and even necessary to understand the present of Literary Studies as a void, that is as a time after a historical ending and without a continuity that will connect it with a specific future. The new enthusiasm for literature will surely find its institutional place - outside or inside the university. And there is not much else left in our institutional present that deserves the investment, intellectual and financial, necessary to make it survive.

\section{REFERENCES}

LYOTARD, Jean François. A condição pós-moderna. Rio de Janeiro: José Olympio, 2002.

FUKUYAMA, Francis. O fim da história e o último homem. In: . A experiência do século. Porto Alegre:

Palmarinca, 1992. 